\title{
VASCULAR PLANTS AND BRYOPHYTES IN MANAGED FORESTS - ANALYSIS OF THE IMPACT OF THE OLD DITCHES ON THE SPECIES DIVERSITY (CENTRAL EUROPEAN PLAIN)
}

\author{
ZIELIŃSKA, K. M. ${ }^{1 *}-$ STANIASZEK-KIK, M. ${ }^{1}-$ MISZTAL, M. ${ }^{2}$ \\ ${ }^{1}$ Department of Geobotany and Plant Ecology, Faculty of Biology and Environmental \\ Protection, University of Lodz, Banacha 12/16, 90-237 Lodz, Poland \\ ${ }^{2}$ Chair of Statistical Methods, Faculty of Economics and Sociology, University of Lodz, \\ Rewolucji 1905r 41; 90-214 Lodz, Poland \\ *Corresponding author \\ e-mail: katarzyna.zielinska@biol.uni.lodz.pl; phone: +48-42-6354404; fax: +48-42-6354660 \\ (Received 14 $4^{\text {th }}$ Jan 2017; accepted 20 $0^{\text {th }}$ Mar 2017)
}

\begin{abstract}
In Central Europe forests, natural habitat heterogeneity, which commonly results from dynamics of canopy gap with soil pits and mounds formation, is to a large extent replaced by anthropogenic disturbances. Vascular plants and bryophytes can profit from anthropogenic habitats occurrence in different ways. Our goal was to study the difference between the reaction of these two taxonomic groups on the occurrence of the old ditches in managed forests. We found that the presence of ditches provides habitats for vascular plants as well as microhabitats for bryophytes and leads to enriching the forest flora within both of these groups. On average the number of species occurring in ditches in comparison to forest interior sites was about $97 \%$ higher in case of vascular plants and $45 \%$ higher in case of bryophytes. The bryophytes were characterized by the bigger dissimilarity of the species composition between the plots in the ditches and in forest interior. The role of the ditches differed between coniferous, mixed and deciduous forest types. In addition, in sites where a significant rise in vascular species richness was noted, bryophytes species enrichment was significantly less than that recorded for the vascular plants. Keywords: habitat diversity, microhabitat, species richness, anthropogenic habitats, forest stand type
\end{abstract}

\section{Introduction}

Habitat diversification in a forest complex may be a result of variation of light conditions, features of soil and presence of coarse woody debris or leaf litter. It is frequently connected to the unevenness in topography and openings in canopy (Beatty, 1984; Canham et al., 1990; Heithecker and Halpern, 2006). Forests used for timber production are cut down before they reach the stage of old-growth hence management reduces the occurrence of treefalls and other minor disturbances. Relatively young and dense stands planted on previously leveled ground are typically characterized by low habitat heterogeneity (Crow et al., 2002; Wohlgemuth et al., 2002). However, in managed forest complexes artificial disturbances like roads, ditches, logging trails etc. may constitute an important source of anthropogenic habitat heterogeneity (Baltzinger et al., 2011; Buckley et al., 2003; Peterken and Francis, 1999).

Habitat heterogeneity, both natural and anthropogenic, is considered an important factor in creating species richness. The body of research into anthropogenic forest structures that has been accumulated to date points to a significant role they play in increasing species richness of forest complexes (e.g. Baltzinger et al., 2011; Bergès et al., 2013; Peterken and Francis, 1999; Smith et al., 2007; Zielińska et al., 2013). For the 
purposes of this study, from the many anthropogenic disturbances occurring in forests the analysis of ditches has been selected. Positive effects of topography on vascular plant and bryophyte species richness have been demonstrated on numerous occasions (eg. Löbel et al., 2006; Ulanova, 2000; Vellak at al., 2003) and ditches belong to the type of disturbances which exert the strongest influence on habitat diversity of forest complexes and which are responsible for the most significant growth of species richness (Baltzinger et al., 2011; Banach, 2009). This analysis focuses on typical drainage ditches intersecting forest phytocoenoses as well as roadside ditches. Beside the fact that both ditch types create different conditions on the bottom and the sides, roadside ditches are characterized by larger sun exposure. The presence of a road lined with a ditch may be of key importance as in many studies of floral diversity of forest complexes it has been demonstrated that it is the roadside that offers the richest habitat for non-forest species (Baltzinger et al., 2011; Zielińska, 2007; Smith et al., 2007).

This paper will attempt to compare the influence of the anthropogenic structures on two contrasting taxonomic groups, namely vascular plants and bryophytes. According to Paillet et al. (2010) who conducted meta-analysis of species richness in managed and unmanaged forests in Europe, the said taxonomic groups respond differently to transformations of forest phytocoenosis caused by man. Vascular plants display higher species richness in managed forests unlike bryophytes, whose resultant species richness is lower. Other researchers also concluded that bryophytes are more sensitive to forest management and even small scale environment alterations (Scott, 1971; Slack, 1990; Vellak et al., 2003; Vellak and Ingerpuu, 2005 and cited).

In comparison to vascular plants, bryophytes do not so directly depend on the features of soil since they lack roots and cuticule and function in forest ecosystems in a different way (Beier et al., 1993; Hettenbergerová et al., 2013; Vellak et al., 2003). Bryophytes inhabit various substrates and numerous authors point to the fact that their diversity is closely associated with the diversity of substrate types (Cole et al., 2008; Evans et al., 2012). It can be stated that bryophytes occupy microhabitats within habitats principally taken by typically larger vascular plants. With such pronounced differences between vascular plants and bryophytes a legitimate question seems to be whether presence of ditches in forests contributes to increased species richness of bryophytes flora to the same degree as has been evidenced in the case of vascular flora (Baltzinger et al., 2011; Zielińska et al., 2013).

The purpose of the study is to compare how anthropogenic structures such as ditches influence the species diversity of two contrasting taxonomic groups: vascular plants and bryophytes and it will seek to address the question of whether the two plant groups respond in a similar or different way to the presence of anthropogenic habitats in deciduous, mixed and coniferous forests. The analysis has been undertaken for drainage ditches directly crossing a forest as well as forest roadside ditches both in terms of the number of species and species composition.

\section{Material and methods}

The study was conducted in central Poland $\left(51^{\circ} 10^{\prime}-52^{\circ} 05^{\prime} \mathrm{N}, 19^{\circ} 05^{\prime}-20^{\circ} 15^{\prime} \mathrm{E}, 180-220 \mathrm{~m}\right.$ altitude) in the years 2007-2009. The climate of the area is suboceanic to moderate continental, with an average temperature and precipitation of about $9^{\circ} \mathrm{C}$ and $550 \mathrm{~mm}$ respectively. The bedrock of the local soils is predominantly sands and clays. The study area is characterized by strongly transformed landscape, highly populated, agricultural and 
urbanized, however it still contains a considerable area of forest complexes (Figure 1). Despite the majority of forest phytocoenoses being cultivated and highly fragmented, they are still a source of regional biodiversity (Rewicz et al., 2015).

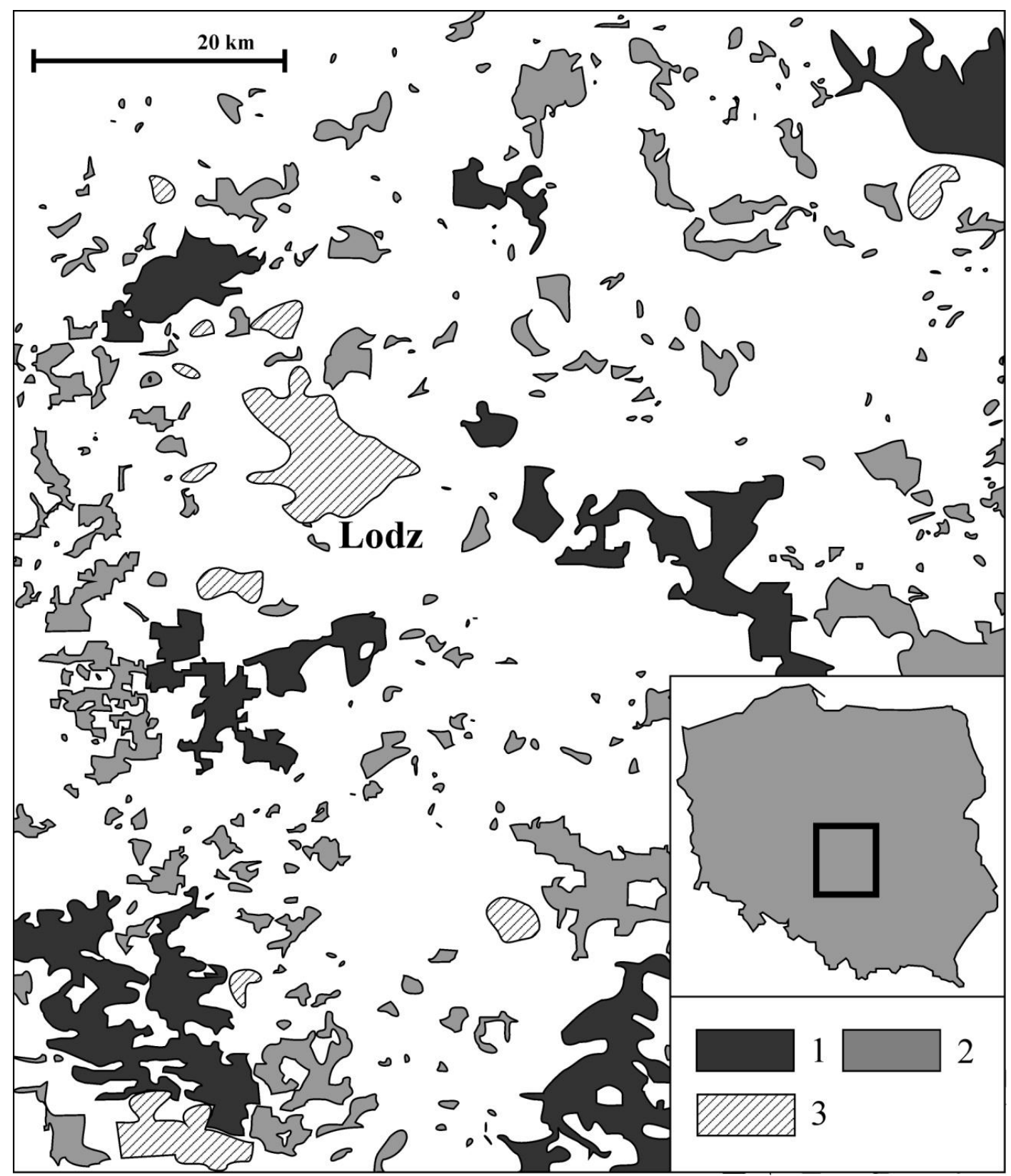

Figure 1. Map of the study area and its location in Poland; (1) forest complexes taken into account in the analysis, (2) other forest complexes (3) urban areas

The forests of central Poland are mostly managed and they occupy approx. $20 \%$ of the land cover where the study was conducted. Past promotion of pine (Pinus sylvestris L.) resulted in most forest complexes now being coniferous and mixed forests (largely on sites of Vaccinio-Piceetea Br.-B1. 1939) (Matuszkiewicz, 2001). Beside pine, the predominant species constituting the stand in the case of the latter is oak, Quercus robur 
L. A smaller area is occupied by deciduous forests (mostly oak-hornbeam forests) on sites of Querco-Fagetea Br.-Bl. et Vlieg. 1937 (Matuszkiewicz, 2001).

All the bigger forest complexes within the study area were searched for drainage ditches beginning from a randomly chosen location. After finding a ditch a plot was established within it and another corresponding control plot was located in the forest (at the distance of approx. 10m from the ditch). The plots were established away from the influence of road presence, clear-cuts or forest edges, at least a dozen meters away from such disturbances. Ditches were characterized by varied width (1-5m, mean $2.6 \mathrm{~m})$ and varied depth $(0.5-1.75 \mathrm{~m}$, mean $0.8 \mathrm{~m})$. The length of the plot in the ditch was $5 \mathrm{~m}$, and the width reflected the width of the ditch. With this method of determining of plots they have different surface, but according to the preliminary studies enlargement of plots even as much as twofold of its surface is not such meaningful as consideration of the whole diversity of microhabitats constituting the ditches with bottom and two slopes (which would not have been taken account if the plots had equal surface in smaller and bigger ditches). The corresponding plots in forests had the same surface area as ditch plots. 40 such pairs of plots of equal surface were established. Subsequently, additional 21 plots were placed in roadside ditches and the same number of corresponding control plots in the surrounding forests. The plots in roadside ditches were only established along unpaved roads, which in contemporary state owned managed forests constitute a characteristic, regular network. A total number of 61 plots were established in ditches and another 61 plots in forests. We chose only the old ditches, which have not been deepened for years. Since accurate identification of forest associations in managed complexes is heavily error prone (they have a simplified structure and altered species composition) the classification has been limited to categorize the studied plots into coniferous, mixed and deciduous forests. Thus 33 pairs of plots (in ditches and forests) have been studied in coniferous forests ( 25 in and near the drainage ditches, 8 in and near the roadside ones), 17 in mixed forests (9-drainage, 8-roadside) and 11 pairs in deciduous forests (6-drainage, 5-roadside). It roughly corresponds to the area occupied by the analyzed forest types within the study area.

Within each plot all the vascular plant species and bryophyte species were listed (see Appendix A). All the existing bryophyte species regardless of their substrate were included. Over the studied area they inhabited exposed soil, humus, dead wood, live trees trunks up to $50 \mathrm{~cm}$ from the base, certain herbaceous plants' stems and even small rocks. Various substrates inhabited by bryophytes within the studied plots were termed microhabitats in the article, in contrast to mesohabitats which represented the area of the size of the ditch. Cover abundance of plant species was visually estimated in the field using the scale: $0.5,5,10,20,30, \ldots, 100 \%$.

During preliminary studies we were trying to find whether the ditch width, depth or percentage of tree and shrub cover had a significant impact on biodiversity indexes (among others we analysed species richness, Shannon's diversity index and Pielou's evenness index with Spearman's rank correlation coefficients), but we did not find clear dependencies neither for vascular plants (Zielińska et al,. 2013) nor for bryophytes.

For the analysis of species richness (dependent variable) mixed model ANOVA was used with plot area as a covariate, plot as a nested random factor and plant type (vascular-bryophyte), forest type (coniferous, mixed, deciduous), ditch type (drainage, roadside) and plot category (ditch - control forest plot) as fixed factors. All possible interactions between studied fixed factors were analysed. Post hoc multiple comparisons were performed using Tukey's HSD test for unequal sample sizes. 
Bray-Curtis similarity index:

$$
\left(1-B C=1-\frac{\sum\left|n_{1 i}-n_{2 i}\right|}{\sum\left(n_{1 i}+n_{2 i}\right)}\right)
$$

where $n_{j i}$ is the cover of species $i$ in sample $j$, was used to quantify the compositional similarity between the ditch and corresponding forest plot for vascular plants and bryophytes separately. Three-way ANOVA was applied to detect differences between both types of plants considering the two ditch types and three types of forest and post hoc multiple comparisons using Tukey's HSD test for unequal sample sizes were performed.

All the necessary assumptions for ANOVA (normality and homogeneity of variances) were met. Normality was tested using Shapiro - Wilk's test for normality. Homogeneity of variances was tested with Levene's test. Results were considered significant for $P<0.05$. All calculations were performed using STATISTICA PL version 10.0 (StatSoft, Inc., 2011) and the vegan package for R 3.0.1 Statistical Software (Oksanen et al., 2013, R Core Team, 2013).

Nomenclature of vascular plant species follows the digital version of the Flora Europaea (Tutin et al., 1964-2010), and Ochyra et al. (2003) and Szweykowski (2006) for bryophytes.

\section{Results}

Over the study period there were identified a total number of 129 vascular plant species and 79 bryophytes taxa, including 13 liverworts (Table 1). In ditches a total number of 128 species of vascular plants and 72 species of bryophytes were reported, while in corresponding plots 55 vascular plant species and 50 bryophytes were found. $57 \%$ of vascular plants and $37 \%$ of bryophytes were only found in plots located in ditches (Table 1). Both in the case of vascular plants and bryophytes there were common species, present simultaneously in ditches and corresponding plots and often characterized by a large degree of coverage for both types of studied plots. It is especially true for coniferous forests with examples such as Vaccinium myrtillus L., $V$. vitis-idaea L., or shrubs, for instance Frangula alnus Mill. Among bryophytes one such species is Pleurozium schreberi (Willd. ex Brid.) Mitt. However, 52\% in the case of vascular plants and $56 \%$ in the case of bryophytes were plants identified only in four or fewer of all the 122 studied plots. It is these rare species that mainly determine the distinctness of flora in ditches. Such accidental species considered separately cannot be treated as indicators of anthropogenic habitats, and only their large number can.

Table 1. The number of species of vascular plants and bryophytes found only in ditches or in corresponding forest control plots, or identified in both types of plots, in brackets: the percentage of the total number of species of vascular plants or bryophytes

\begin{tabular}{ccccc}
\hline \multirow{2}{*}{ Type of plant } & ditch only & forest only & ditch and forest & total \\
\hline Vascular plants & $74(57.4 \%)$ & $1(0.8 \%)$ & $54(41.9 \%)$ & 129 \\
Bryophytes & $29(36.7 \%)$ & $7(8.9 \%)$ & $43(54.4 \%)$ & 79 \\
\hline
\end{tabular}


Both the mean species richness of vascular plants and the mean species richness of bryophytes were considerably higher in plots located in ditches in comparison to the control plots in forests (Table 2, 3; Figure 2). It is noteworthy that in the case of vascular plants the difference between the species richness found in ditches and in the surrounding forests was considerably higher than in the case of bryophytes. Since the analysis of variance indicated that the interaction between type of plot (ditch correspondence), type of plant (vascular - bryophytes) and the forest type (coniferous, mixed, deciduous) was relevant (Table 2), the post-hoc Tukey's tests were conducted. In the case of coniferous forests both the mean number of vascular plants and bryophytes were significantly higher in plots located in ditches than in control forest plots. In the case of mixed and deciduous forests significant differences have been found only for vascular plants (Table 3).

Table 2. Mixed model ANOVA results for species number; the grouping variables refer to taxonomic affiliation to vascular plants or bryophytes $(V-B)$, plot location in a ditch or forest $(D-F)$, forest type (coniferous, mixed, deciduous) and ditch type (drainage or roadside). Plot area was entered as covariate

\begin{tabular}{lccccc}
\hline Factors nad interactions & SS & df & MS & F & $\boldsymbol{P}$ \\
\hline Plot area & 237.79 & 1 & 237.8 & 14.74 & $\mathbf{0 . 0 0 0 2}$ \\
Vascular-Bryophyta (V-B) & 712.26 & 1 & 712.3 & 44.16 & $<\mathbf{0 . 0 0 0 1}$ \\
Forest type & 89.41 & 2 & 44.7 & 2.77 & 0.0670 \\
Ditch type & 13.13 & 1 & 13.1 & 0.81 & 0.3689 \\
Ditch-Forest (D-F) & 188.76 & 1 & 188.8 & 16.21 & $\mathbf{0 . 0 0 0 1}$ \\
Plot area*D-F & 0.35 & 1 & 0.3 & 0.03 & 0.8630 \\
V-B *Forest type & 98.26 & 2 & 49.1 & 3.05 & 0.0516 \\
V-B *Ditch type & 6.68 & 1 & 6.7 & 0.41 & 0.5212 \\
V-B*D-F & 348.70 & 1 & 348.7 & 29.95 & $<\mathbf{0 . 0 0 0 1}$ \\
Forest type *Ditch type & 45.66 & 2 & 22.8 & 1.42 & 0.2473 \\
D-F*Forest type & 25.99 & 2 & 13.0 & 1.12 & 0.3313 \\
D-F* Ditch type & 24.17 & 1 & 24.2 & 2.08 & 0.1525 \\
V-B *Forest type *Ditch type & 225.90 & 2 & 112.9 & 7.00 & $\mathbf{0 . 0 0 1 4}$ \\
V-B * D-F *Forest type & 93.74 & 2 & 46.9 & 4.03 & $\mathbf{0 . 0 2 0 6}$ \\
V-B *D-F *Ditch type & 9.06 & 1 & 9.1 & 0.78 & 0.3796 \\
D-F *Forest type *Ditch type & 59.72 & 2 & 29.9 & 2.56 & 0.0816 \\
V-B * D-F *Forest type *Ditch type & 72.81 & 2 & 36.4 & 3.13 & $\mathbf{0 . 0 4 7 8}$ \\
\hline
\end{tabular}

The relationship of the two analyzed plant types' response to the ditch presence was not significantly determined by ditch type - both drainage and roadside ditches contributed similarly to species richness (Table 2). Statistical significance, however, had been noted for interaction between all the analysed covariables. This was due to the fact that in the case of vascular plants the difference in species abundance observed in plots in ditches and forests was determined by the ditch and forest type while the number of bryophytes did not exhibit pronounced variations (Table 3, Figure 2). The biggest difference in species richness was noted for vascular plants occurring in roadside 
ditches and in control plots in deciduous and mixed forests. Quite the reverse pattern was observed in coniferous forests where there is no statistical significance for the results obtained for roadside ditches but the results are statistically significant for drainage ditches. In mixed forests, the average number of vascular plant species reported in the ditches was significantly higher than that of the forests regardless of ditch type (Table 3, Figure 2).

Table 3. Descriptive statistics for the species number identified in ditch plots and the corresponding forest plots (ditch/forest) according to selected interactions $\left(D-F^{*} V-B, D\right.$ $F^{*} V-B^{*}$ Forest type and $D-F^{*} V-B^{*}$ Forest type*Ditch type) with the results of post hoc Tukey's HSD tests

\begin{tabular}{|c|c|c|c|c|c|c|c|}
\hline \multicolumn{2}{|c|}{$\begin{array}{l}\text { Total; } \\
\text { Forest type; Ditch } \\
\text { type }\end{array}$} & $\begin{array}{l}\text { Vascular (V); } \\
\text { Bryophyta (B) }\end{array}$ & Mean & SD & Min & Max & $\begin{array}{c}P \\
(D \text { vs F })\end{array}$ \\
\hline \multirow{2}{*}{\multicolumn{2}{|c|}{ 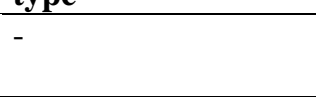 }} & $\mathrm{V}$ & $15.57 / 7.89$ & $5.72 / 3.87$ & $4 / 0$ & $26 / 22$ & 0.0001 \\
\hline & & B & $9.95 / 6.87$ & $3.46 / 2.86$ & $2 / 1$ & $17 / 12$ & 0.0001 \\
\hline \multirow{2}{*}{\multicolumn{2}{|c|}{ coniferous }} & $\mathrm{V}$ & $14.36 / 8.09$ & $5.11 / 3.46$ & $4 / 0$ & $26 / 15$ & 0.0001 \\
\hline & & B & $10.06 / 6.36$ & $3.33 / 2.69$ & $3 / 1$ & $15 / 11$ & 0.0016 \\
\hline \multirow{2}{*}{\multicolumn{2}{|c|}{ mixed }} & V & $15.88 / 6.18$ & $6.28 / 2.83$ & $4 / 2$ & $26 / 12$ & 0.0001 \\
\hline & & B & $10.65 / 7.41$ & $3.55 / 3.12$ & $2 / 1$ & $17 / 12$ & 0.2105 \\
\hline \multirow{2}{*}{\multicolumn{2}{|c|}{ deciduous }} & V & $18.73 / 9.91$ & $5.80 / 5.39$ & $10 / 5$ & $25 / 22$ & 0.0001 \\
\hline & & B & $8.55 / 7.55$ & $3.59 / 2.91$ & $4 / 2$ & $14 / 12$ & 0.9999 \\
\hline \multirow{4}{*}{ coniferous } & drainage & $\mathrm{V}$ & $14.76 / 8.00$ & $5.52 / 3.84$ & $4 / 0$ & $26 / 15$ & 0.0002 \\
\hline & & B & $10.56 / 7.08$ & $2.96 / 2.45$ & $3 / 1$ & $15 / 11$ & 0.0724 \\
\hline & roadside & V & $13.13 / 8.38$ & $3.56 / 2.00$ & $8 / 6$ & $18 / 12$ & 0.4605 \\
\hline & & B & $8.50 / 4.13$ & $4.14 / 2.23$ & $3 / 1$ & $15 / 8$ & 0.6258 \\
\hline \multirow{4}{*}{ mixed } & drainage & $\mathrm{V}$ & $13.00 / 5.22$ & $6.36 / 2.44$ & $4 / 2$ & $23 / 10$ & 0.0012 \\
\hline & & B & $12.44 / 7.44$ & $2.30 / 4.00$ & $10 / 1$ & $17 / 12$ & 0.2510 \\
\hline & roadside & $\mathrm{V}$ & $19.13 / 7.25$ & $4.61 / 3.01$ & $13 / 3$ & $26 / 12$ & 0.0002 \\
\hline & & B & $8.63 / 7.38$ & $3.74 / 2.00$ & $2 / 5$ & $14 / 9$ & 1.0000 \\
\hline \multirow[t]{4}{*}{ deciduous } & $\begin{array}{l}\text { drainage } \\
\text {. }\end{array}$ & $\mathrm{V}$ & $19.33 / 12.83$ & $6.71 / 5.81$ & $10 / 6$ & $25 / 22$ & 0.1623 \\
\hline & & B & $6.67 / 7.83$ & $1.97 / 2.40$ & $4 / 4$ & $9 / 11$ & 1.0000 \\
\hline & roadside & V & $18.00 / 6.40$ & $5.15 / 1.52$ & $11 / 5$ & $24 / 9$ & 0.0003 \\
\hline & & B & $10.80 / 7.20$ & $3.96 / 3.70$ & $4 / 2$ & $14 / 12$ & 0.9919 \\
\hline
\end{tabular}

Apart from the analysis of species richness, this study focused also on the analysis of the similarity of the studied plots in terms of their species composition and species cover. The analysis of Bray-Curtis similarity measure indicated that bryophytes distinguished between ditch plots and control plots to a larger degree than vascular plants. Three-way ANOVA demonstrated that the differences of the plots located in ditches and in forests expressed with Bray-Curtis similarity values counted for vascular plants (mean $0.44 \pm 0,20$ ) and for bryophytes (mean $0.34 \pm 0,17$ ) were statistically significant $(F=6.821, \mathrm{df}=1, P=0.0103)$. However the relationship of the mentioned values with the location of plots in different forest and ditch types was not statistically significant. The conclusion that among the taxa present in ditches, it was the bryophytes that were characterized by more dissimilarity in comparison to forest flora was a result of the larger number of species which were exclusively or much more frequently noted in corresponding control plots. One could list here for example Amblystegium serpens (Hedw.) Schimp., Orthodicranum tauricum (Sapjegin) Smirnova or Orthodontium lineare Schwägr. present only in forest plots or Orthodicranum montanum (Hedw.) 
Loeske which was much more frequent in forest plots. Apart from Convallaria majalis L. which was not noted in ditch plots, among the vascular plants there were no species preferring forest habitats. Majority of herbaceous forest species were also found in ditches. Among bryophytes noteworthy were also the species occurring much more frequently in ditches or in control plots within a given habitat type of forests. For instance, Atrichum undulatum (Hedw.) P.Beauv. occurred only in ditches in coniferous forests, but in mixed and deciduous forests it was also reported in control plots. Sciurohypnum oedipodium (Mitt.) Ignatov \& Huttunen was found both in ditches and in control plots in coniferous forests, whereas in mixed and deciduous forests it was much more frequent in ditches (in corresponding control plots this species was found only twice and it occupied only a small area). On the other hand, Herzogiella seligeri (Brid.) Z.Iwats. was found more often in ditches in coniferous forests, and in mixed and deciduous forests it was only identified in control plots.

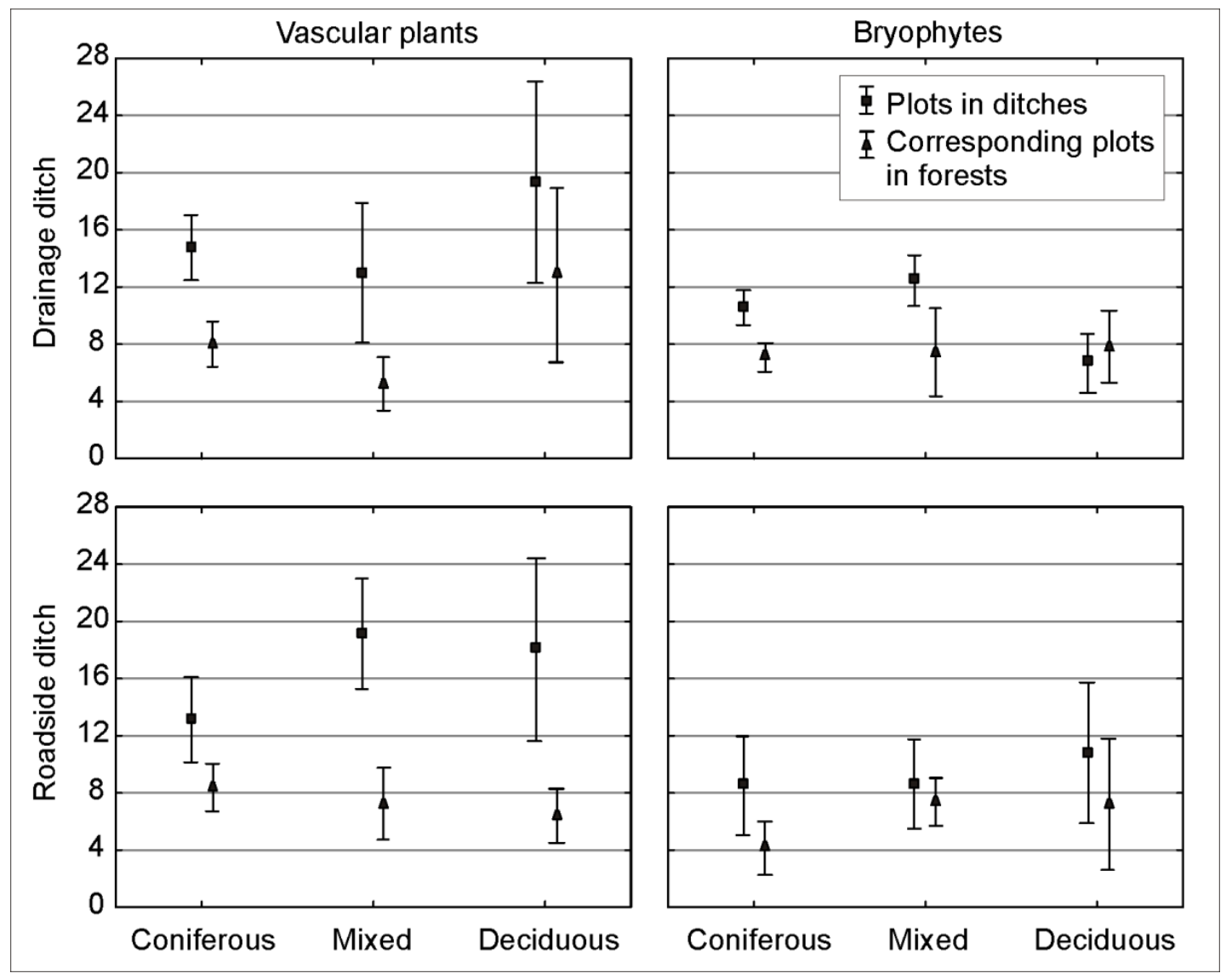

Figure 2. Impact of ditch presence expressed in species richness (mean $\pm 95 \%$ confidence intervals)

\section{Discussion}

In regard to the species richness understood as the total number of plants identified in research plots of a given type, the plots established in ditches significantly differed from the corresponding control plots in the surrounding forests. The flora in ditches can be characterized not only by a larger number of species but also by the presence of plants which have not been encountered in the forest. A similar pattern has been reported in 
other studies. The research of Baltzinger et al. (2011) conducted in ancient royal forest of Tronçais (centre of France) who also compared plots located in drainage ditches with forest control plots proved that one half of the identified species were present only in ditches. The studies of Banach (2009) undertaken in Polesie National Park (Eastern Poland) have also pointed to the increased species richness and specificity of flora in ditches in comparison with forest phytocoenoses. It has to be stressed that the increase of species richness described in this study concerned both vascular plants and bryophytes. Positive correlation of bryophyte and herb richness in forests has also been described by other authors e.g. Ingerpuu et al. (2001) and Evans et al. (2012). Löbel et al. (2006) have in turn demonstrated a positive effect of microtopography on vascular plant and bryophyte species richness in grasslands. They argue that their research supports the hypothesis that spatial heterogeneity facilitates the coexistence of species. Simultaneously, there are researchers who claim that higher light levels characterizing structures such as glades, rides and roads existing in planted forests increase species richness of vascular plants and decrease species richness of bryophytes (Smith et al., 2007). In contrast to the above mentioned structures, ditches represent the type of habitat which is not only frequently light penetrated but which can be primarily characterized by moister soils than forest habitats (Zielińska et al., 2013).

The analysis of mean values of species richness noted in particular types of plots (plots in ditches - corresponding plots) yielded similar results with almost twice as many vascular plant species and almost a 50\% higher number of bryophytes identified in ditches than in forests. Although the significantly higher number of species in ditches characterized both analysed taxonomic groups, the presence of ditches had impacted the richness of vascular plants to a considerably higher degree. The independent behaviour of the moss and herb layers in the case of habitat conditions change had been shown in numerous studies both in forest and meadow phytocoenoses (Hettenbergová et al., 2013; Kull et al., 1995; Niinemets and Kull, 2005; Ingerpuu et al., 1998; Vellak et al., 2003). Such pattern could partly be explained by the fact that regional species pool for both taxonomic groups is different, in our case the number of bryophytes to be found in the area under analysis is lower. It has to be pointed, however, that in central Poland over 300 bryophytes species have been noted so far (Staniaszek-Kik and Wolski, 2009) and that in the case of bryophytes being cryptogams with very small diaspores and distinctly larger distribution ranges dispersal limitation may be less common in comparison to vascular plants (Löbel et al., 2006). Thus it is not the smaller regional species pool that has determined the significantly lower growth of bryophytes species richness in comparison to the vascular plants. Moreover Shmida and Wilson (1985) stated that the main factor facilitating the species diversity in the adopted study scale is the variety of habitats and microhabitats. Bryophytes are plants that can settle on even the smallest of habitable substrates and therefore microhabitats have been claimed to be more important for them than mesohabitats (Vitt and Belland, 1997; Mills and Macdonald, 2004). In the course of this study significant diversification of plots from the point of view of bryophyte species richness was noted with their number greater in plots with old tree stumps and live trees with vast root bases as well as wild boar rooting traces. The presence of varied substrates was of key importance for the richness of this taxonomic group, probably more important than the topographic variety introduced by ditches. Ditches facilitated the occurrence of different substrate types needed by bryophytes, e.g. by accumulating various sizes of decaying wood or organic debris, 
fragments of exposed soil or small stones. Their presence, however, was not as significant to bryophytes as to vascular plants.

The variance analysis performed for the number of species pointed to the significance of the forest type. Minor differences between the impact of ditch presence on the richness of the two analysed taxonomic groups have been noted for coniferous forests. It is noteworthy that the increase of species richness in ditches noted for vascular plants in coniferous forests was lower than that noted for mixed and deciduous forests but for bryophytes we did not observe the same pattern. Therefore in mixed and deciduous forests the presence of a ditch impacted the species richness of bryophytes in a much different way than the richness of vascular plants. In compliance with the principles adopted for forest management over the studied area, the homogenous pine stands were planted on soils characterized by the lowest nutrient content, the deciduous stands, to the contrary, on the most eutrophic soils, hence coniferous, mixed and deciduous forests reflect the soil trophy gradient. It has been noted due to the fact that many studies point to a different response of vascular plants and bryophytes to changes of trophy (eg. Ingerpuu et al., 1998). Also in experimental studies analysing the effects of fertilization, an increase in the number of herbs and a decline in the number of bryophytes has been reported (Aude and Ejrnæs, 2005; Bates, 2008). As has been demonstrated here, the presence of anthropogenic variety of habitats in forests with higher trophy favors a much larger number of vascular plants species than bryophytes. Only in coniferous forests, where bryophytes constitute a much more significant ingredient of ground cover (Barbier et al., 2008; Hart and Chen, 2006) the presence of more humid habitats such as ditches caused the increase of their number to a degree comparable with vascular plants. It could be speculated that the decreasing number of bryophytes along with the corresponding changes in soil trophy reflects the resultant increased competitiveness of vascular plants but verification of such a hypothesis would demand further research.

The type of the analysed ditch did not impact the number of species as significantly as forest type. In coniferous pine forests, which are naturally more light penetrated (Hart and Chen, 2006), the presence of the road did not have such a significant impact on the degree of alteration of habitats as was the case with mixed and deciduous forests. As expected, in roadside ditches of mixed and deciduous forests there was a significant increase in the number of species but it characterized only vascular plants. The number of bryophytes also rose but the increase was not so significant. The similar conclusion can be drawn as in the case of forest type analysis: those additional anthropogenic habitats which allow for a large increase of vascular plant species richness at the same time create less opportunity for enlargement of bryophyte richness. This is coincident with the results of other authors, who claim that vascular plants respond to forest management in a different manner than other analysed forest species - e.g. bryophytes but also lichens and fungi among others (Paillet et al., 2010). Among the species which spontaneously inhabit the forest communities management favors vascular plants.

Bray-Curtis similarity measure analysis showed that the plots located in ditches display a higher dissimilarity in comparison to plots located in the surrounding forests due to the presence of bryophytes. Three elements contributed to the result. Firstly, the presence among bryophytes of a group of species occurring exclusively in corresponding control plots, secondly, the fact that numerous taxa display distinct preferences for ditches or forests within one habitat type of forest, and thirdly, similarly to vascular plants, the presence of a large number of species existing only in ditches. A 
group of bryophytes species which was rarely to be found in ditches were species connected with tree barks and root bases as well as tree stumps remaining after thinning. Distinct preferences for ditches or forests plots depending on forest type were related to the ecology of the given species, for instance Atrichum undulatum (Hedw.) P.Beauv. prefers fertile settlements with $\mathrm{pH}$ close to neutral and that is why in coniferous forests it was only found in ditches while in mixed and deciduous forests it was also reported in forest control plots. A more detailed analysis concerning the bryophytes alone have been published in the separate article devoted to this taxonomic group (Staniaszek-Kik et al., 2016). However, although the bryophyte species composition in ditches was distinct we could not distinguish such a group of species that could be considered as typical for ditches. It was because the majority of species occurred at low frequencies. Among bryophytes occurring only in ditches, the most frequent was Oxyrrhynchium hians (Hedw.) Loeske, which was noted only 7 times.

Even though a larger number of non-forest vascular plants and bryophytes, including synatrophic, were noted in ditches, there was no indication that ditches constitute a migration route for invasive species, a number of alien taxa was not larger there than in corresponding control plots. From the perspective of protection of natural diversity of flora in forest complexes, it is very positive. The acquired results point to the conclusion that the flora of ditches corresponds to the flora of areas through which they run. The presence of ditches enriches the local taxa pool primarily with accidental species, both associated with forest and non-forest habitats. This is the case for both the taxonomic groups under study. It could be hypothesized that old drainage ditches constitute an element of anthropogenically shaped landscape which may to a certain extent substitute the missing in managed forests topographic, wetness and light diversification of unmanaged forests where there are pits and mounds around root plates of fallen trees.

\section{Conclusions}

Research into the influence of management on the species heterogeneity of forest complexes most often concentrates on macroarea disturbances such as clear-cutting or single-crop farming over large areas. This analysis of the presence of the old drainage ditches in managed forests demonstrated that even small and additionally anthropogenic structures disturbing the topographic evenness of the area may be a source of habitats for numerous species and impact the biodiversity of a forest complex as such. The presence of ditches in managed forests leads to the significant increase of species richness regarding both the vascular plants and bryophytes. In the case of vascular plants the flora of ditches was primarily characterized by a larger number of noted species and in the case of bryophytes more important was not the number of species itself but the species composition. Bryophytes flora of ditches was lacking species found on tree barks and root bases but was richer in species of initial habitats or hygrophilous ones. Still, the analysis presented here has indirectly demonstrated that the presence of ditches is a source of habitat diversification both at meso- and microscales.

\section{REFERENCES}

[1] Aude, E., Ejrnæs, R. (2005): Bryophyte colonisation in experimental microcosms: the role of nutrients, defoliation and vascular vegetation. - Oikos 109(2): 323-330. DOI: $10.1111 / \mathrm{j} .0030-1299.2005 .13268 . x$ 
[2] Baltzinger, M., Archaux, F., Gosselin, M., Chevalier, R. (2011): Contribution of forest management artefacts to plant diversity at a forest scale. - Annals of Forest Science 68: 395-406.

[3] Banach, B. (2009): Vascular flora of drainage ditches in forest area of the Polesie National Park. - Acta Agrobotanica 62(1): 117-126.

[4] Barbier, S., Gosselin, F., Balandier, P. (2008): Influence of tree species on understory vegetation diversity and mechanisms involved - A critical review for temperate and boreal forests. - Forest Ecology and Management 254(1): 1-15.

[5] Bates, J. W. (2008): Mineral nutrition and substratum ecology. - In: Goffinet, E., Shaw, A.J. (eds) Bryophyte biology ( $2^{\text {nd }}$ edition). Cambridge University Press, NY.

[6] Beatty, S. W. (1984): Influence of Microtopography and Canopy Species on Spatial Patterns of Forest Understory Plants. - Ecology 65(5): 1406-1419.

[7] Beier, C., Hansen, K., Gundersen, P. (1993): Spatial variability of throughfall fluxes in spruce forest. - Environmental Pollution 81: 257-267.

[8] Bergès, L., Chevalier, R., Avon, C. (2013): Influence of forest road, road-surfacing material and stand age on floristic diversity and composition in a nutrient-poor environment. - Applied Vegetation Science 16: 470-479.

[9] Buckley, D. S., Crow, T. R., Nauertz, E. A., Schulz, K. E. (2003): Influence of skid trails and haul roads on understory plant richness and composition in managed forest landscapes in Upper Michigan, USA. - Forest Ecology and Management 175: 509-520.

[10] Canham, C. D., Denslow, J. S., Platt, W. J., Runkle, J. R., Spies, T. A., White, P. S. (1990): Light regimes beneath closed canopies and tree-fall gaps in temperate and tropical forests. - Canadian Journal of Forest Research 20(5): 620-631. DOI: $10.1139 / \times 90-084$

[11] Cole, H.A., Steven, G., Newmaster, F., Bell, W., Pitt, D., Stinsond, A. (2008): Influence of microhabitat on bryophyte diversity in Ontario mixedwood boreal forest. - Canadian Journal of Forest Research 38(7): 1867-1876. DOI: 10.1139/X08-036

[12] Crow, T. R., Buckley, D. S., Nauertz, E. A., Zasada, J. C. (2002): Effects of management on the composition and structure of northern hardwood forests in Upper Michigan. Forest Science 48: 129-145.

[13] Evans, S. A., Halpern, C. B., McKenzie, D. (2012): The contributions of forest structure and substrate to bryophyte diversity and abundance in mature coniferous forests of the Pacific Northwest. - The Bryologist 115(2): 278-294. DOI: 10.1639/0007-2745115.2.278

[14] Hart, S. A., Chen, H. Y. H. (2006): Understory vegetation dynamics of North American boreal forests. - Critical Reviews in Plant Sciences 25: 381-397.

[15] Heithecker, T. D., Halpern, C. B. (2006): Variation in microclimate associated with dispersed-retention harvests in coniferous forests of western Washington. - Forest Ecology and Management 226: 60-71.

[16] Hettenbergerová, E., Hájek, M., Zelený, D., Jiroušková, J., Mikulášková, E. (2013): Changes in species richness and species composition of vascular plants and bryophytes along a moisture gradient. - Preslia 85: 369-388.

[17] Ingerpuu, N., Kull, K., Vellak, K. (1998): Bryophyte vegetation in a wooded meadow: relationships with phanerogam diversity and responses to fertilization. - Plant Ecology 134: 163-171.

[18] Ingerpuu, N., Vellak, K., Kukk, T., Pärtel, M. (2001): Bryophyte and vascular plant species richness in boreo-nemoral moist forests and mires. - Biodiversity and Conservation 10: 2153-2166.

[19] Kull, O., Aan, A., Sõelsepp, T. (1995): Light Interception, Nitrogen and Leaf Mass Distribution in a Multilayer Plant Community. - Functional Ecology 9(4): 589-595.

[20] Löbel, S., Dengler, J., Hobohm, C. (2006): Speciesrichness of vascular plants, bryophytes and lichens in dry grasslands: the effects of environment, landscape structure and competition. - Folia Geobotanica 41: 377-393. 
[21] Matuszkiewicz, W. (2001): Guide to the determination of plant communities in Poland. PWN, Warsaw. [in Polish]

[22] Mills, S. E., Macdonald, S. E. (2004): Predictors of moss and liverwort species diversity of microsites in conifer-dominated boreal forest. - Journal of Vegetation Science 15: 189198.

[23] Niinemets, Ü., Kull, K. (2005): Co-limitation of plant primary productivity by nitrogen and phosphorus in a species-rich wooded meadow on calcareous soils. - Acta Oecologica 28(3): 345-356. DOI: 10.1016/j.actao.2005.06.003

[24] Ochyra, R., Żarnowiec, J., Bednarek-Ochyra, H. (2003): Census catalogue of Polish mosses. Biodiversity of Poland. Vol. 3. - Polish Academy of Sciences, Institute of Botany, Kraków.

[25] Oksanen, J., Blanchet, F. G., Kindt, R., Legendre, P., Minchin, P. R., O'Hara, R. B., Simpson, G. L., Solymos, P., Stevens, M. H. H., Wagner, H. (2013): vegan: Community Ecology Package. R package version 2.0-8. URL http://vegan.r-forge.r-project.org/

[26] Paillet, Y., Bergès, L., Hjältén, J., Ódor, P., Avon, C., Bernhardt-Römermann, M., Bijlsma, R-J., De Bruyn, L., Fuhr, M., Grandin, U., et al. (2010): Biodiversity differences between managed and unmanaged forests: meta-analysis of species richness in Europe. Conservation Biology 24(1): 101-112.

[27] Peterken, G. F., Francis, J. L. (1999): Open spaces as habitats for vascular ground flora species in the woods of central Lincolnshire, UK. - Biological Conservation 91(1): 55-72.

[28] R Core Team. (2013): R: A language and environment for statistical computing. R Foundation for Statistical Computing, Vienna, Austria. ISBN 3-900051-07-0, URL http://www.R-project.org/

[29] Rewicz, A., Zielińska, K. M., Kiedrzyński, M., Kucharski, L. (2015): Orchidaceae in the anthropogenic landscape of central Poland: diversity, extinction and conservation perspectives. - Archives of Biological Science Belgrade 67(1): 119-130. DOI:10.2298/ABS140428014R

[30] Scott, G. A. M. (1971): Some problems in the quantitative ecology of bryophytes. - New Zealand Journal of Botany 9: 744-749.

[31] Shmida, A., Wilson, M. V. (1985): Biological Determinants of Species Diversity. Journal of Biogeography 12(1): 1-20.

[32] Slack, N. G. (1990): Bryophytes and ecological niche theory. - Botanical Journal of the Linnean Society 104: 187-213.

[33] Smith, G. F., Iremonger, S., Kelly, D.L., O’Donoghue, S., Mitchell, F. J. G. (2007): Enhancing vegetation diversity in glades, rides and roads in plantation forests. Biological Conservation 136(2): 283-294.

[34] Staniaszek-Kik, M., Zielińska, K. M., Misztal, M. (2016): How do ditches contribute to bryophyte diversity in managed forests in East-Central Europe? - Europaean Journal of Forest Research 135(4): 621-632. DOI:10.1007/s10342-016-0959-6

[35] Staniaszek-Kik, M., Wolski, G. J. (2009): Bryophytes - diversity, changes and threats. In: Kurowski, J. K. (ed.) Vegetation of Central Poland. Towarzystwo Ochrony Krajobrazu, Wydawnictwo EKO-GRAF, Łódź. [in Polish]

[36] StatSoft, Inc. (2011): STATISTICA (data analysis software system), version 10. URL www.statsoft.com.

[37] Szweykowski, J. (2006): An annotated checklist of polish liverworts and hornworts. - W. Szafer Institute of Botany, Polish Academy of Sciences, Krakow.

[38] Tutin, T. G. et al. (eds) (1964-2010): Flora Europaea. - Cambridge University Press, Cambridge.

[39] Ulanova, N. G. (2000): The effects of windthrow on forests at different spatial scales: a review. - Forest Ecology and Management 135: 155-167.

[40] Vellak, K., Ingerpuu, N. (2005): Management Effects on Bryophytes in Estonian Forests. - Biodiversity \& Conservation 14(13): 3255-3263. 
[41] Vellak, K., Paal, J., Liira, J. (2003): Diversity and distribution pattern of bryophytes and vascular plants in a boreal spruce forest. - Silva Fennica 37(1): 3-13.

[42] Vitt, D. H., Belland, R. J. (1997): Attributes of rarity among Alberta mosses: patterns and prediction of species diversity. - Bryologist 100: 1-12.

[43] Wohlgemuth, T., Bürgi, M., Scheidegger, C., Schütz, M. (2002): Dominance reduction of species through disturbance - a proposed management principle for central European forests. - Forest Ecology and Management 166: 1-15.

[44] Zielińska, K. M. (2007): The influence of roads on the species diversity of forest vascular flora in Central Poland. - Biodiversity: Research and Conservation 5-8: 71-80.

[45] Zielińska, K.M., Misztal, M., Zielińska, A., Żywiec, M. (2013): Influence of Ditches on Plant Species Diversity in the Managed Forests of Central Poland. - Baltic Forestry 19(2): 270-279.

\section{APPENDIX}

\section{Appendix A. Supplementary material}

The list of collected species divided into vascular plants and bryophytes with the Rarity Index values obtained for plots in ditches (D), corresponding plot in forests (F) and for the total number of plots. Rarity Index (Ir) was calculated using the formula $\operatorname{Ir}=(\mathrm{N}-\mathrm{n}) / \mathrm{N}$, where $\mathrm{N}$ is the total number of plots and $\mathrm{n}$ is the number of plots in which the species appears; the value 1.00 means that the species was not found on a single plot of the given category, the value 0.00 that it occurred in the all analysed plots (Géhu 1979); species were ranked in descending order of the index value; * means the alien species.

\begin{tabular}{|c|c|c|c|c|c|c|c|c|}
\hline Lp. & Vascular plants & D & $\mathbf{F}$ & Total & Bryophytes & D & $\mathbf{F}$ & Total \\
\hline 1 & Vaccinium myrtillus L. & 0,60 & 0,57 & 0,17 & $\begin{array}{l}\text { Lophocolea heterophylla } \\
\text { (Schrad.) Dumort. }\end{array}$ & 0,75 & 0,66 & 0,40 \\
\hline 2 & Frangula alnus Mill, & 0,61 & 0,73 & 0,34 & $\begin{array}{l}\text { Pleurozium schreberi (Willd. } \\
\text { ex Brid) Mitt. }\end{array}$ & 0,78 & 0,75 & 0,53 \\
\hline 3 & Rubus sp. & 0,65 & 0,81 & 0,46 & $\begin{array}{l}\text { Dicranella heteromalla } \\
\text { (Hedw.) Schimp. }\end{array}$ & 0,67 & 0,87 & 0,54 \\
\hline 4 & Quercus robur L. & 0,73 & 0,76 & 0,49 & Pohlia nutans (Hedw.)Lindb. & 0,75 & 0,80 & 0,55 \\
\hline 5 & Sorbus aucuparia L. & 0,81 & 0,77 & 0,58 & $\begin{array}{l}\text { Plagiomnium affine (Blandow } \\
\text { ex Funck) T.J.Kop. }\end{array}$ & 0,70 & 0,88 & 0,58 \\
\hline 6 & Luzula pilosa (L.) Willd. & 0,71 & 0,88 & 0,59 & Plagiothecium laetum Schimp. & 0,83 & 0,76 & 0,59 \\
\hline 7 & Vaccinium vitis-idaea $\mathrm{L}$. & 0,80 & 0,80 & 0,60 & $\begin{array}{l}\text { Sciuro-hypnum oedipodium } \\
\text { (Mitt.) Ignatov. \& Huttunen }\end{array}$ & 0,79 & 0,81 & 0,60 \\
\hline 8 & $\begin{array}{l}\text { Dryopteris carthusiana (Vill.) } \\
\text { H. P. Fuchs }\end{array}$ & 0,73 & 0,87 & 0,60 & $\begin{array}{l}\text { Plagiothecium denticulatum } \\
\text { (Hedw.) Schimp. }\end{array}$ & 0,72 & 0,89 & 0,61 \\
\hline 9 & $\begin{array}{l}\text { Molinia caerulea (L.) } \\
\text { Moench }\end{array}$ & 0,80 & 0,82 & 0,61 & $\begin{array}{l}\text { Plagiothecium curvifolium } \\
\text { Schlieph. ex Limpr. }\end{array}$ & 0,80 & 0,82 & 0,61 \\
\hline 10 & Lysimachia vulgaris L. & 0,74 & 0,93 & 0,67 & $\begin{array}{l}\text { Polytrichastrum formosum } \\
\text { (Hedw.) G.L.Sm. }\end{array}$ & 0,73 & 0,91 & 0,64 \\
\hline 11 & Oxalis acetosella L. & 0,81 & 0,89 & 0,70 & $\begin{array}{l}\text { Atrichum undulatum (Hedw.) } \\
\text { P.Beauv. }\end{array}$ & 0,73 & 0,97 & 0,70 \\
\hline 12 & Stellaria media (L & 0,82 & 0,89 & 0,70 & $\begin{array}{l}\text { Herzogiella seligeri (Brid.) } \\
\text { Z.Iwats. }\end{array}$ & 0,89 & 0,84 & 0,73 \\
\hline 13 & $\begin{array}{l}\text { Pteridium aquilinum (L.) } \\
\text { Kuhn }\end{array}$ & 0,85 & 0,87 & 0,72 & $\begin{array}{l}\text { Orthodicranum montanum } \\
\text { (Hedw.) Loeske }\end{array}$ & 0,97 & 0,78 & 0,75 \\
\hline 14 & Populus tremula L. & 0,85 & 0,89 & 0,75 & Hypnum cupressiforme Hedw. & 0,93 & 0,82 & 0,75 \\
\hline 15 & Trientalis europaea $\mathrm{L}$. & 0,91 & 0,86 & 0,77 & Tetraphis pellucida Hedw. & 0,91 & 0,87 & 0,78 \\
\hline
\end{tabular}


16 Deschampsia cespitosa (L.) P. Beauv

17 Agrostis sp.

18 Carpinus betulus L.

19 Viola reichenbachiana Jordan ex Bor.

20 Maianthemum bifolium (L.) F. W. Schmidt

21 Carex pilulifera $\mathrm{L}$.

22 Juncus effusus L.

23 Milium effusum L.

24

Athyrium filix-femina (L.) Roth

25 Agrostis stolonifera L.

26 Stellaria holostea L.

27 Poa sp.

28 Calamagrostis arundinacea (L.) Roth

29 Carex ovalis Gooden.

30 Carex sp.

31 Betula pendula Roth

32 Picea abies (L.) H. Karst.

33 Dryopteris dilatata (Hoffm.) A. Gray

34 Salix cinerea L.

35 Viola palustris L.

36 Abies alba Mill.

37 Equisetum sylvaticum L.

38 Betula pubescens Ehrh.

39 Melampyrum pratense L.

40 Peucedanum palustre (L.) Moench

41 Prunus serotina Ehrh.*

42 Fagus sylvatica L.

43 Tilia cordata Mill.

44 Carex hirta L.

45

$\begin{array}{lll}0,83 & 0,94 & 0,77 \\ 0,84 & 0,95 & 0,79 \\ 0,89 & 0,90 & 0,80 \\ 0,84 & 0,95 & 0,80 \\ 0,91 & 0,89 & 0,80 \\ 0,88 & 0,93 & 0,80 \\ 0,84 & 1,00 & 0,84 \\ 0,90 & 0,95 & 0,85 \\ 0,87 & 0,98 & 0,85 \\ 0,85 & 1,00 & 0,85 \\ 0,92 & 0,95 & 0,87 \\ 0,93 & 0,95 & 0,88 \\ 0,91 & 0,97 & 0,88 \\ 0,90 & 0,98 & 0,88 \\ 0,90 & 0,98 & 0,89 \\ 0,94 & 0,95 & 0,89 \\ 0,94 & 0,95 & 0,89 \\ 0,93 & 0,96 & 0,89 \\ 0,90 & 1,00 & 0,90 \\ 0,90 & 1,00 & 0,90 \\ 0,97 & 0,95 & 0,92 \\ 0,92 & 1,00 & 0,92 \\ 0,96 & 0,97 & 0,93 \\ 0,96 & 0,98 & 0,93 \\ 0,93 & 1,00 & 0,93 \\ 0,98 & 0,96 & 0,94 \\ 0,98 & 0,97 & 0,94 \\ 0,97 & 0,98 & 0,94 \\ 0,99 & 0,94 \\ 0,94 \\ 0.95\end{array}$

Brachythecium rutabulum

(Hedw.) Schimp.

Brachytheciastrum velutinum

(Hedw.) Ignatov \& Huttunen

Dicranum scoparium Hedw.

Hypnum jutlandicum Holmen

\& E.Warncke

Lepidozia reptans (L.)

Dumort.

Aulacomnium androgynum

(Hedw.) Schwägr.

Sphagnum fallax (H.Klinggr.)

H.Klinggr.

Pseudoscleropodium purum

(Hedw.) M.Fleisch. ex Broth.

Brachythecium salebrosum

(Hoffm. ex F.Weber \&

D.Mohr) Schimp.

Dicranum polysetum Sw.

Lophocolea bidentata (L.)

Dumort.

Polytrichum commune Hedw.

Calypogeia azurea Stotler \&

Crotz

Hypnum pallescens (Hedw.)

P.Beauv.

Calypogeia muelleriana

(Schiffn.) Müll.Frib.

Kindbergia praelonga (Hedw.)

Ochyra

Cephalozia bicuspidata (L.)

Dumort.

Oxyrrhynchium hians (Hedw.)

Loeske

Pohlia melanodon (Brid.)

A.J.Shaw

Hylocomium splendens

(Hedw.) Schimp.

Orthodicranum flagellare

(Hedw.) Loeske

Ptilidium pulcherrimum

(Weber) Vain.

Aulacomnium palustre

(Hedw.) Schwägr.

Fissidens bryoides Hedw.

Plagiomnium undulatum

(Hedw.) T.J.Kop.

Amblystegium serpens

(Hedw.) Schimp.

Polytrichastrum longisetum

(Sw. ex Brid.) G.L.Sm.

Cephaloziella divaricata (Sm.) Schiffn.

Ceratodon purpureus (Hedw.) Brid.

Hypnum cupressiforme var. filiforme Brid. $\begin{array}{lll}0,84 & 0,93 \quad 0,78\end{array}$

$0,92 \quad 0,91 \quad 0,83$

$\begin{array}{lll}0,92 & 0,93 & 0,84\end{array}$

$\begin{array}{lll}0,91 & 0,96 & 0,87\end{array}$

$\begin{array}{lll}0,89 & 0,98 & 0,87\end{array}$

$\begin{array}{lll}0,96 & 0,92 \quad 0,88\end{array}$

$\begin{array}{lll}0,89 & 0,99 & 0,89\end{array}$

$\begin{array}{lll}0,92 & 0,98 & 0,89\end{array}$

$\begin{array}{lll}0,95 & 0,95 & 0,90\end{array}$

$0,95 \quad 0,95 \quad 0,90$

$0,93 \quad 0,98 \quad 0,90$

$0,92 \quad 0,98 \quad 0,90$

$\begin{array}{lll}0,91 & 0,99 & 0,90\end{array}$

$\begin{array}{lll}0,98 & 0,93 & 0,92\end{array}$

$\begin{array}{lll}0,94 & 0,98 & 0,93\end{array}$

$\begin{array}{lll}0,94 & 0,99 & 0,93\end{array}$

$\begin{array}{lll}0,95 & 0,99 & 0,94\end{array}$

$\begin{array}{lll}0,94 & 1,00 \quad 0,94\end{array}$

$\begin{array}{lll}0,96 & 0,99 & 0,95\end{array}$

$\begin{array}{lll}0,97 & 0,99 & 0,96\end{array}$

$\begin{array}{lll}0,99 & 0,98 & 0,97\end{array}$

$0,98 \quad 0,99 \quad 0,97$

$0,97 \quad 1,00 \quad 0,97$

$0,97 \quad 1,00 \quad 0,97$

$0,97 \quad 1,00 \quad 0,97$

$1,00 \quad 0,98 \quad 0,98$

$0,99 \quad 0,98 \quad 0,98$

$0,98 \quad 0,99 \quad 0,98$

$0,98 \quad 0,99 \quad 0,98$

$0,98 \quad 0,99 \quad 0,98$ 
46

47 Pinus sylvestris L.

48 Quercus rubra L.*

49 Corylus avellana L.

Deschampsia flexuosa (L.) Trin.

51 Ajuga reptans L.

52 Lysimachia nummularia L.

53 Prunella vulgaris L.

54 Ranunculus repens L.

55 Stellaria palustris Hoffm.

56 Urtica dioica L.

57 Melica nutans L.

58 Prunus padus L.

59 Glyceria sp.

60 Hieracium acuminatum Jord. $\quad 0,96 \quad 1,00 \quad 0,96$

61 Lycopus europaeus L.

62 Mycelis muralis (L.) Dumort. $0,96 \quad 1,00 \quad 0,96$

63 Alnus glutinosa (L.) Gaertn. $\quad 0,98 \quad 0,99 \quad 0,97$

64 Veronica officinalis L.

65 Aegopodium podagraria L.

66 Cirsium sp.

67 Geum urbanum L.

68 Scrophularia nodosa L.

69 Veronica chamaedrys L.

70 Convallaria majalis L.

71 Juniperus communis L.

72 Glechoma hederacea L.

73 Hieracium sabaudum L

74 Cerastium fontanum Baumg. $\quad 0,98 \quad 1,00 \quad 0,98$

75 Fragaria vesca L.

76 Galium palustre L.

77 Rubus idaeus L.

78 Scutellaria galericulata L.
$0,96 \quad 1,00 \quad 0,96$

$0,94 \quad 1,00 \quad 0,94$

$0,94 \quad 1,00 \quad 0,94$

$0,99 \quad 0,96 \quad 0,95$

$0,98 \quad 0,98 \quad 0,95$

$0,97 \quad 0,98 \quad 0,95$

$0,96 \quad 0,99 \quad 0,95$

$0,95 \quad 1,00 \quad 0,95$

$0,95 \quad 1,00 \quad 0,95$

$0,95 \quad 1,00 \quad 0,95$

$0,95 \quad 1,00 \quad 0,95$

$\begin{array}{lll}0,95 & 1,00 \quad 0,95\end{array}$

$\begin{array}{lll}0,98 & 0,98 & 0,96\end{array}$

$0,98 \quad 0,98 \quad 0,96$

$0,96 \quad 1,00 \quad 0,96$

$\begin{array}{lll}0,98 & 0,99 \quad 0,97\end{array}$

$0,97 \quad 1,00 \quad 0,97$

$\begin{array}{lll}0,97 & 1,00 & 0,97\end{array}$

$0,97 \quad 1,00 \quad 0,97$

$0,97 \quad 1,00 \quad 0,97$

$\begin{array}{lll}0,97 & 1,00 & 0,97\end{array}$

$1,00 \quad 0,98 \quad 0,98$

$0,99 \quad 0,98 \quad 0,98$

$\begin{array}{lll}0,98 & 0,99 & 0,98\end{array}$

$\begin{array}{lll}0,98 & 0,99 & 0,98\end{array}$

$0,98 \quad 1,00 \quad 0,98$

$\begin{array}{lll}0,98 & 1,00 & 0,98\end{array}$

$\begin{array}{lll}0,98 & 1,00 & 0,98\end{array}$

$\begin{array}{lll}0,98 & 1,00 & 0,98\end{array}$
Leucobryum glaucum (Hedw.)

Ångstr.

Platygyrium repens (Brid.)

Schimp.

Pellia epiphylla (L.) Corda

Rhizomnium punctatum

(Hedw.) T.J.Kop.

Rosulabryum laevifilum

(Syed) Ochyra

Calliergon cordifolium

(Hedw.) Kindb.

Cirriphyllum piliferum

(Hedw.) Grout

$0,98 \quad 0,99 \quad 0,98$

$0,98 \quad 1,00 \quad 0,98$

$0,98 \quad 1,00 \quad 0,98$

$0,99 \quad 0,99 \quad 0,98$

$0,98 \quad 1,00 \quad 0,98$

$0,98 \quad 1,00 \quad 0,98$

Funaria hygrometrica Hedw. $\quad 0,98 \quad 1,00 \quad 0,98$

Plagiomnium cuspidatum

(Hedw.) T.J.Kop.

Sphagnum fimbriatum Wilson

Warnstorfia fluitans(Hedw.)

Loeske

Bryum caespiticium Hedw.

Calypogeia fissa (L.) Raddi

Eurhynchium striatum

(Schreb. ex Hedw.) Schimp.

Orthodicranum tauricum

(Sapjegin) Smirnova

Orthodontium lineare

Schwägr*

Polytrichastrum pallidisetum

(Funck) G.L.Sm.

Chiloscyphus polyanthos (L.)

Corda

Eurhynchium

angustirete(Broth.) T.J.Kop.

Eurhynchium sp.

Leptodictyum riparium

(Hedw.) Warnst.

Lophozia bicrenata (Schmidel ex Hoffm.) Dumort.

Pellia sp.

Plagiomnium ellipticum

(Brid.) T.J. Kop.

Plagiothecium cavifolium

(Brid.) Z.Iwats.

Plagiothecium nemorale

(Mitt.) A.Jaeger

$0,98 \quad 1,00 \quad 0,98$

$\begin{array}{lll}0,98 & 1,00 & 0,98\end{array}$

$0,98 \quad 1,00 \quad 0,98$

$\begin{array}{lll}1,00 & 0,99 & 0,99\end{array}$

$\begin{array}{lll}1,00 & 0,99 & 0,99\end{array}$

$\begin{array}{lll}1,00 & 0,99 & 0,99\end{array}$

$\begin{array}{lll}1,00 & 0,99 & 0,99\end{array}$

$\begin{array}{lll}1,00 & 0,99 & 0,99\end{array}$

$\begin{array}{lll}1,00 & 0,99 & 0,99\end{array}$

$0,99 \quad 1,00 \quad 0,99$

$\begin{array}{lll}0,99 & 1,00 & 0,99\end{array}$

$\begin{array}{lll}0,99 & 1,00 & 0,99\end{array}$

$\begin{array}{lll}0,99 & 1,00 & 0,99\end{array}$

$0,99 \quad 1,00 \quad 0,99$

$\begin{array}{lll}0,99 & 1,00 & 0,99\end{array}$

$\begin{array}{lll}0,99 & 1,00 & 0,99\end{array}$

$\begin{array}{lll}0,99 & 1,00 & 0,99\end{array}$

$0,99 \quad 1,00 \quad 0,99$

Pohlia wahlenbergii (F.Weber

\& D.Mohr) A.L.Andrews

Polytrichum juniperinum

Hedw.

$0,99 \quad 1,00 \quad 0,99$

$\begin{array}{lll}0,99 & 1,00 & 0,99\end{array}$

Rhytidiadelphus squarrosus

(Hedw.) Warnst.

Rosulabryum capillare

(Hedw.) J.R.Spence

Sphagnum girgensohnii

Russow

Sphagnum palustre L.

Thuidium tamariscinum
$0,99 \quad 1,00 \quad 0,99$

$\begin{array}{lll}0,99 & 1,00 & 0,99\end{array}$

$\begin{array}{lll}0,99 & 1,00 & 0,99\end{array}$

$0,99 \quad 1,00 \quad 0,99$

$\begin{array}{lll}0,99 & 1,00 & 0,99\end{array}$ 
79 Torilis japonica (Houtt.) DC.

80 Tussilago farfara $\mathrm{L}$.

Dryopteris filix-mas (L.)

81 Schott

82 Epilobium sp.

83 Fraxinus excelsior $\mathrm{L}$.

84 Lamiastrum galeobdolon (L.)

Ehrend. \& Polatschek

85 Anemone nemorosa L.

86 Anthoxanthum odoratum L.

87 Calluna vulgaris (L.) Hull

88 Carex acutiformis Ehrh.

89 Festuca ovina L.

90 Filipendula ulmaria (L.) Maxim.

91 Geranium robertianum L.

92 Iris pseudacorus L.

93 Lapsana communis L.

94 Mentha sp.

95 Ranunculus acris L.

96 Rumex acetosella L.

97 Rumex obtusifolius L. Valeriana officinalis subsp.

98 sambucifolia (J.C. Mikan) Čelak.

99 Acer pseudoplatanus L.

100 Aesculus hippocastanum L.*

101 Agrimonia eupatoria L.

102 Brachypodium sp.

103 Calamagrostis epigejos (L.) Roth

104 Carex digitata L.

105 Crataegus monogyna Jacq.

106 Dactylis glomerata L.

107 Equisetum arvense L.

108 Galium sp.

109 Hypericum perforatum L.

110 Lathyrus pratensis L.

111 Ledum palustre $\mathrm{L}$.

112 Luzula sp.

113 Lycopodium clavatum L.

114 Medicago lupulina L.

115 Orthilia secunda (L.) House

116 Oxalis europaea Jord.*

117 Populus alba L.

118 Ribes spicatum E. Robson

119 Salix sp.

120 Sambucus racemosa L.

121 Solidago virgaurea $L$.

122 Stachys sylvatica L.

123 Stellaria nemorum L.

124 Tanacetum vulgare $\mathrm{L}$.
(Hedw.) Schimp.

Ulota crispa (Hedw.) Brid. $\quad 0,99 \quad 1,00 \quad 0,99$ $\begin{array}{lll}0,98 & 1,00 & 0,98\end{array}$

$\begin{array}{lll}0,98 & 1,00 & 0,98\end{array}$

$\begin{array}{lll}0,99 & 0,99 & 0,98\end{array}$

$\begin{array}{lll}0,99 & 0,99 & 0,98\end{array}$

$\begin{array}{lll}0,99 & 0,99 & 0,98\end{array}$

$\begin{array}{lll}0,99 & 0,99 & 0,98\end{array}$

$0,98 \quad 1,00 \quad 0,98$

$\begin{array}{lll}0,98 & 1,00 & 0,98\end{array}$

$0,98 \quad 1,00 \quad 0,98$

$\begin{array}{lll}0,98 & 1,00 & 0,98\end{array}$

$\begin{array}{lll}0,98 & 1,00 & 0,98\end{array}$

$0,98 \quad 1,00 \quad 0,98$

$0,98 \quad 1,00 \quad 0,98$

$\begin{array}{lll}0,98 & 1,00 & 0,98\end{array}$

$\begin{array}{lll}0,98 & 1,00 & 0,98\end{array}$

$0,98 \quad 1,00 \quad 0,98$

$0,98 \quad 1,00 \quad 0,98$

$0,98 \quad 1,00 \quad 0,98$

$\begin{array}{lll}0,98 & 1,00 & 0,98\end{array}$

$0,98 \quad 1,00 \quad 0,98$

$\begin{array}{lll}0,99 & 1,00 & 0,99\end{array}$

$\begin{array}{lll}0,99 & 1,00 & 0,99\end{array}$

$\begin{array}{llll}0,99 & 1,00 & 0,99\end{array}$

$\begin{array}{llll}0,99 & 1,00 & 0,99\end{array}$

$\begin{array}{lll}0,99 & 1,00 & 0,99\end{array}$

$\begin{array}{lll}0,99 & 1,00 & 0,99\end{array}$

$\begin{array}{lll}0,99 & 1,00 & 0,99\end{array}$

$\begin{array}{lll}0,99 & 1,00 & 0,99\end{array}$

$\begin{array}{lll}0,99 & 1,00 & 0,99\end{array}$

$\begin{array}{lll}0,99 & 1,00 & 0,99\end{array}$

$\begin{array}{llll}0,99 & 1,00 & 0,99\end{array}$

$\begin{array}{llll}0,99 & 1,00 & 0,99\end{array}$

$\begin{array}{lll}0,99 & 1,00 & 0,99\end{array}$

$\begin{array}{lll}0,99 & 1,00 & 0,99\end{array}$

$\begin{array}{lll}0,99 & 1,00 & 0,99\end{array}$

$\begin{array}{lll}0,99 & 1,00 & 0,99\end{array}$

$\begin{array}{lll}0,99 & 1,00 & 0,99\end{array}$

$\begin{array}{lll}0,99 & 1,00 & 0,99\end{array}$

$\begin{array}{lll}0,99 & 1,00 & 0,99\end{array}$

$\begin{array}{llll}0,99 & 1,00 & 0,99\end{array}$

$\begin{array}{llll}0,99 & 1,00 & 0,99\end{array}$

$\begin{array}{llll}0,99 & 1,00 & 0,99\end{array}$

$\begin{array}{lll}0,99 & 1,00 & 0,99\end{array}$

$\begin{array}{lll}0,99 & 1,00 & 0,99\end{array}$

$\begin{array}{lll}0,99 & 1,00 & 0,99\end{array}$

$\begin{array}{lll}0,99 & 1,00 & 0,99\end{array}$ 
125 Taraxacum officinale aggr.

126 Thelypteris palustris Schott

127 Trifolium repens L.

128 Ulmus sp.

129 Vicia sp.

$\begin{array}{lll}0,99 & 1,00 & 0,99 \\ 0,99 & 1,00 & 0,99 \\ 0,99 & 1,00 & 0,99 \\ 0,99 & 1,00 & 0,99 \\ 0,99 & 1,00 & 0,99\end{array}$

Géhu JM, editor. 1979. Étude phytocoenotique analytique et globale de l'ensemble des vases et prés salés et saumâtres de la facade atlantique francaise. Bailleul: Faculté de Farmacie, Univ. De Lille II et Station de Phytosociologie. 